\title{
Religious holidays and analysts forecast optimism: Evidence from MENA countries
}

\author{
Harit Satt $\mathrm{a}^{*}$ \\ a School of Business Administration, Al Akhawayn University in Ifrane, Morocco \\ *Corresponding author's email address: H.Satt@aui.ma
}

\section{A R T I C L E IN F O}

Received: 10-12-2015

Revised submission: 25-05-2016

Accepted: 29-06-2016

Available online: 29-07-2016

Keywords:

Analyst Recommendations;

Holidays effect;

Optimism.

JEL Classification:

G15; G20.

(C) 2016 The Authors. This is an open access article under the terms of the Creative Commons Attribution License 4.0, which allows use, distribution, and reproduction in any medium provided the original work is properly cited.

DOI: http://dx.doi.org/10.18533/jefs.v4i3.249

\begin{abstract}
A B S T R A C T
We investigate the effect of religious holidays on analyst recommendation on stock markets in MENA countries stock markets (Morocco, United Arab Emirates, Saudi Arabia, Jordan, Kuwait, Lebanon, Qatar, Algeria, Bahrain) for the period of 2004 to 2015. The result shows that on pre-holidays, analysts tend to issue pessimistic recommendations, and issue optimistic recommendations on post-holidays ${ }^{1}$. Prior literature on day-of -the week effect is consonant with our results which document an increase in stock prices during the week, and a decrease in stock prices over the weekend. We argue that analysts can benefit from the upward trend in stock prices during Post-Holidays by issuing an optimistic recommendation. Analysts may as well benefit from the downward trend in stock prices by issuing pessimistic recommendations on pre-holidays. We also exhibit that our results are more consistent among less experienced analysts and in firms with greater information uncertainty.
\end{abstract}

ISSN 2379-9463(Print), ISSN 2379-9471(Online)

\section{$1.0 \quad$ Introduction}

Religious values and practice have a significant effect on economic growth (Barro \& McCleary 2003). We use Muslim holy days to study the latent mechanism of the effects of holidays. Muslim holy days are particularly useful to restraining the holy day effect. During Ramadan, the study reveals a positive change in stock returns.

Religion affects people in their daily life, in their decision-making, preferences, etc. Religion is a vital concern in people's lives. As religion affects people in such matters, this paper capitalizes on holy events to study the underlying mechanisms behind the holiday effect and to try to learn about how the stock market along with analysts' recommendations can be affected.

There are several Muslim holidays in the Arabic world, but in this paper, we will mainly focus on Eid al-Fitr and Eid al-Adha and Eid-al Mawlid. People in different countries celebrate those events in different ways, but the values and meaning are the same. These holidays are common in a family gathering and going to the mosque, and according to a study conducted in U.S on Health and Retirement, people who visit families and neighbors or go to church are more likely to invest in stocks (Hong et al. 2004). Same findings have been determined using a British panel survey. Following the same logic, we can claim that during these events, social interactions lead to a positive

\footnotetext{
${ }^{1}$ Post holidays are the period before Eid al-Fitr and Eid al-Adha and Eid-al Mawlid; three terms relating to Muslims holyfestival.
} 
impact on the stock's market activities. Studies have been done on the Jewish events, and a study shows that after St. Patrick's and Rosh Hashanah there are positive returns, but returns turn negative after Yom Kippur, Solemn (Yatrakis and Williams, 2010). Other research conducted on lunar months such as Ramadan, Shawal, etc. and their effect on the Tehran stock market and the findings reveal a positive relationship (Ramezani, Pouraghajan and Mardani, 2013).

Several papers have investigated types of behavioral biases in analyst recommendations (Grossman and Stiglitz 1980; Hong, Kubik and Solomon 2000; Hong and Kubik 2003; Trueman 1994; Welch 2000). Some showed that analysts tend to issue more optimistic recommendations, mainly in emerging markets (Lin and McNichols, 1998). The same had been investigated by Satt (2015) addressing that average analyst recommendation is close to a Buy recommendation. Related studies show that analysts are hesitant about issuing negative recommendations since sell or underperform recommendation sum a total of less than 5 percent of all recommendations issued.

Another research shows that more than half of the recommendations issued are favorable and that unfavorable ones only make up less than 15 percent of all recommendations issued in G7 countries (Jegadeesh and Kim, 2006) and Satt (2016). Many regulators and financial economists claim that an analyst's career improvement has little to do with predicting accurately. They report that analysts' recommendations are optimistically biased (Brown, Foster, and Noreen 1985; Stickel 1990; Abarbanell 1991; Dreman and Berry 1995 and Chopra 1998).

There obviously are reasons for these inflated number of optimistic recommendations. These reasons are associated with the work environment, as shown in a study, analysts who are optimistic relative to the norms are less likely to experience unfavorable job separations, the study also revealed that brokerage houses reward analysts who are optimistic and who generate investment banking business and trading commissions (Harrison Hong, Jefrey D. Kubik, 2005). The same study shows that analysts who issue a large fraction of optimistic forecasts on the stocks that they follow are 90 percent more likely to move up the hierarchy. A survey was done by Michaely and Womack (1999) to understand whether the optimism bias is based on conflicts of interest or other justifications like cognitive bias, the answers favored the conflicts of interest explanation. This paper argues that interaction between the need to generate brokerage commissions and accuracy concerns may result in a situation where analysts are tempted to issue relatively more favorable (optimistic) recommendations on post-holidays and relatively less favorable (pessimistic) recommendations on pre-holidays. This situation is known as the Holidays Effect in analyst recommendations. We relied on prior literature on the day-of-the-week effect in return to the state that Holidays' effect can also exist in analyst recommendations (French, 1980; Lakonishok and Smidt, 1988; Solnik and Bousquet, 1990; Barone, 1990). According to it, stock returns tend to be relatively low on PostHolidays, and relatively high on Pre-Holidays. The day-of-the-week effect in returns also suggests that stock returns are relatively high during the week and tend to decrease during weekends. We affirm that returns are the lowest on Post-Holidays and the highest during the Pre-Holidays. If the statement holds, analysts may be encouraged to issue more favorable recommendations on Post-Holidays because it will relief the pressures from employers concerning the issuance of optimistic recommendations. On the second hand, analysts may also benefit from the movement in stock prices based on their recommendations since it is proven in a study that analysts' recommendations influence stock prices (Loh, R. K., \& Stulz, R. M. 2011) Since holiday's effect indicate an increase in stock prices during the week of holidays, analysts can issue pessimistic recommendations during Pre-Holidays to better optimize between pressure to generate brokerage commissions and their reputational concerns. Since there is a downward trend in stock prices over the week of holidays, according to the Holiday's Effect, if the pessimistic recommendation is issued on Post-Holidays their performance may improve.

This paper asserts that there is an impact of holiday's effect on analyst recommendations. Adopting analyst recommendation data from ten Mena stock markets (Morocco, United Arab Emirates, Saudi Arabia, Jordan, Kuwait, Lebanon, Qatar, Algeria, Bahrain and Yemen) during the period between 2004 and 2015, we could reveal that on Post-Holidays (two days after), analysts issue excessively optimistic recommendations, while on PreHolidays (two days before), analysts issue excessively pessimistic recommendation.

After controlling for several firm-specific characteristics, these findings are quite vigorous to alternate measure of optimism. We showed that the tendency of analysts issuing a Strong Buy or a Buy recommendation is higher on Pre-Holidays period, and again the tendency of analysts issuing an Underperform or Sell recommendation tend to be higher on Post-Holidays. Our results also show that firms with higher information uncertainty enhance the holiday's effect, we argue that whenever information uncertainty is high, reputational concerns for analysts gets lower. Following the same logic, it is somewhat easier for the analysts to issue optimistically biased recommendations for firms with increased level of information uncertainty. Throughout the paper, we also argue that holidays' effect is more prevalent among less experienced analysts. There is more pressure for these analysts from their employers; in consequence, there is a higher likelihood that they will issue optimistic recommendations. On the other hand, advanced analysts are less likely to issue optimistic recommendations as they are more skilled, they have wider networks and have more expertise. The effect of Muslim holidays on analyst 
recommendations is a theme that hasn't been much explored, so we would like to mention that to the best of our knowledge, this is the first evidence regarding the theme.

Following sections of this paper will be structured as follow: Section 2 summarizes the data. Section 3 presents an assessment of our arguments, and Section 4 document robustness of our analysis. Section 5 discusses some of the implications of our results and the paper ends with Section 6 where we present conclusions.

\subsection{The Muslim holidays}

The Islamic calendar is used in Muslim countries and by Muslims worldwide to date events and holy days. It is a lunar calendar composed of twelve lunar months a year (Lee and Hamzah 2010). The Gregorian calendar doesn't include Muslim events because they depend on the sighting of the moon, and therefore changes day and month in Gregorian calendar over years (Chowdhury and Mostari 2015).

The lunar Hijrah calendar begins with Muharram which is a holy month for Muslims, but only the $10^{\text {th }}$ day named Ashura is the most sanctified among its days (Satt 2016). One of the most influential events in the Islamic calendar is Eid al-Adha, it is a sacrifice feast which falls on the 10th day of Dhu al-Hijjah. It is the second Eid celebrated worldwide, and is considered to be the holiest. It celebrates the readiness of Ibrahim (Abraham) to sacrifice his son as compliance to God's command before God intervened by sending his angel Jibrail (Gabriel) and communicate that the sacrifice was already accepted. During this period people tend to spend a great amount of money about other months, it is curious to study the behavior of trading activities in such situations (Chowdhury and Mostari 2015).

Ramadan is the $9^{\text {th }}$ month of the Hijri calendar. The date is also revealed by monitoring the moon movements. It is one of the most celebrated worldwide among Muslims (Bialkowsiki, Etabari and Wisniewski 2010). The month of Ramadan is perceived by Muslims throughout the world as a month of fasting to honor the first revelation of the Quran to Muhamad based on Islamic belief. During this holy month of Ramadan people experience a series of emotion; although fasting promotes patience, devotion, and worship, it also intensifies emotions and senses. Theoretically, Ramadan can impact financial markets due to its effect on investors' reasoning.

Eid al-Fitr is an event that points the end of Ramadan. It falls on Shawwal which is the month that follows the month of Ramadan on the Islamic calendar. The event represents the breaking of the fasting month. It is well known for giving charity to needy people, family and friends gathering, and celebrating the accomplishment of the previous month (Al-Hajieh et al. 2011). Eid al-Mawlid an-Nabawi is the date that marks the birth of the Prophet Muhammad which is celebrated on Rabi al-awwal, the third month in the Islamic calendar, specifically the 12th day of that month.

\subsection{Data}

This study attempts to investigate holiday's effect on analyst recommendations. For our analysis, we will be using firms in the MENA region throughout the period between 2004 and 2015. The data will be more discussed in the following sub sections.

\subsection{Analyst recommendations}

I/B/E/S International history recommendation is a database from where investors can obtain different recommendations and estimations from different analysts. We also used this system to gather data about analyst recommendations. I/B/E/S has its 5-point rating system coded as follow: $1=$ Strong Buy, $2=$ Buy, $3=$ Hold, $4=$ Underperform, $5=$ Sell. The system converts the original text recommendations to one of the point listed above. The sample used in our study includes three events: Eid al-Fitr, Eid al-Adha, and Eid-al Mawlid. We gathered data for five trading days chosen as follow: 2 trading days before the event, the day of the event, and two days after the event. Table 1 shows the descriptive statistics for analyst recommendations. Our findings are consistent with prior literature showing that analysts issue fewer pessimistic recommendations (Jegadeesh and Kim, 2006).

In our sample, we observed that $20 \%$ of recommendations are Underperform or Sell and by far $45 \%$ of recommendations are Strong Buy or Buy. According to a study, downgrades lower analyst recommendations and their commissions; therefore, analysts tend to avoid issuing downgrade recommendations Satt (2015). Conflict of interests being the pressure that analysts face into generating brokerage commissions resulted in a significant disparity existing between the percentage of optimistic recommendations being the Strong Buy and Buy and the pessimistic recommendations being Underperform and Sell (Lin and McNichols, 1998; Barber et al., 2007). 


\begin{tabular}{|c|c|c|c|c|c|c|}
\hline Country & $\begin{array}{r}\text { Strong } \\
\text { Buy }\end{array}$ & Buy & Hold & $\begin{array}{r}\text { Under } \\
\text { perform }\end{array}$ & Sell & TOTAL \\
\hline Morocco & $\begin{array}{r}686 \\
(15,63 \%)\end{array}$ & $\begin{array}{r}1217 \\
(27,71 \%)\end{array}$ & $\begin{array}{r}1639 \\
(37,30 \%)\end{array}$ & $\begin{array}{r}681 \\
(15,51 \%)\end{array}$ & $\begin{array}{r}169 \\
(3,86 \%)\end{array}$ & $\begin{array}{r}4393 \\
(100,00 \%)\end{array}$ \\
\hline Saudi Arabia & $\begin{array}{r}443 \\
(24,37 \%)\end{array}$ & $\begin{array}{r}455 \\
(25,02 \%)\end{array}$ & $\begin{array}{r}656 \\
(36,02 \%)\end{array}$ & $\begin{array}{r}32 \\
(1,77 \%)\end{array}$ & $\begin{array}{r}233 \\
(12,83 \%)\end{array}$ & $\begin{array}{r}1820 \\
(100,00 \%)\end{array}$ \\
\hline Jordan & 675 & 1221 & 467 & 87 & 1126 & 3576 \\
\hline Kuwait & $\begin{array}{r}222 \\
(19,58 \%)\end{array}$ & $\begin{array}{r}443 \\
(39,07 \%)\end{array}$ & $\begin{array}{r}223 \\
(19,66 \%)\end{array}$ & $\begin{array}{r}134 \\
(11,82 \%)\end{array}$ & $\begin{array}{r}112 \\
(9,88 \%)\end{array}$ & $\begin{array}{r}1134 \\
100,00 \%\end{array}$ \\
\hline United Arab Emirates & $\begin{array}{r}1233 \\
(26,06 \%)\end{array}$ & $\begin{array}{r}1124 \\
(23,76 \%)\end{array}$ & $\begin{array}{r}543 \\
(11,48 \%)\end{array}$ & $\begin{array}{r}984 \\
(20,80 \%)\end{array}$ & $\begin{array}{r}847 \\
(17,90 \%)\end{array}$ & $\begin{array}{r}4731 \\
100,00 \%\end{array}$ \\
\hline Qatar & $\begin{array}{r}983 \\
(28,71 \%)\end{array}$ & $\begin{array}{r}776 \\
(22,66 \%)\end{array}$ & $\begin{array}{r}843 \\
(24,62 \%)\end{array}$ & $\begin{array}{r}633 \\
(18,49 \%)\end{array}$ & $\begin{array}{r}189 \\
(5,52 \%)\end{array}$ & $\begin{array}{r}3424 \\
100,00 \%\end{array}$ \\
\hline Lebanon & $\begin{array}{r}198 \\
(20,69 \%)\end{array}$ & $\begin{array}{r}244 \\
(25,50 \%)\end{array}$ & $\begin{array}{r}212 \\
(22,15 \%)\end{array}$ & $\begin{array}{r}190 \\
(19,85 \%)\end{array}$ & $\begin{array}{r}113 \\
(11,81 \%)\end{array}$ & $\begin{array}{r}957 \\
100,00 \%\end{array}$ \\
\hline Algeria & $\begin{array}{r}234 \\
(32,50 \%)\end{array}$ & $\begin{array}{r}211 \\
(29,31 \%)\end{array}$ & $\begin{array}{r}109 \\
(15,14 \%)\end{array}$ & $\begin{array}{r}78 \\
(10,83 \%)\end{array}$ & $\begin{array}{r}88 \\
(12,22 \%)\end{array}$ & $\begin{array}{r}720 \\
100,00 \%\end{array}$ \\
\hline Yemen & $\begin{array}{r}89 \\
(20,55 \%)\end{array}$ & $\begin{array}{r}142 \\
(32,79 \%)\end{array}$ & $\begin{array}{r}98 \\
(22,63 \%)\end{array}$ & $\begin{array}{r}78 \\
(18,01 \%)\end{array}$ & $\begin{array}{r}26 \\
(6,00 \%)\end{array}$ & $\begin{array}{r}433 \\
100,00 \%\end{array}$ \\
\hline Bahrain & $\begin{array}{r}234 \\
(36,85 \%)\end{array}$ & $\begin{array}{r}115 \\
(18,11 \%)\end{array}$ & $\begin{array}{r}178 \\
(28,03 \%)\end{array}$ & $\begin{array}{r}89 \\
(14,02 \%)\end{array}$ & $\begin{array}{r}19 \\
(2,99 \%)\end{array}$ & $\begin{array}{r}635 \\
100,00 \% \\
\end{array}$ \\
\hline
\end{tabular}

This table documents the number and percentage of each type of recommendation. The sample period is between 2004 and 2015. The sample consists of firms listed in (Morocco, United Arab Emirates, Saudi Arabia, Jordan, Kuwait, Lebanon, Qatar, Algeria, Bahrain, and Yemen)

\subsection{Recommendation optimism}

Optimism is the tendency to expect the most favorable results and to focus on the most favorable side of an event. In our research optimism is defined as the divergence between the current analyst's recommendation and the previous' month consensus recommendation (Lai and Teo, 2008; Farooq and Taouss, 2012). Where the average of all outstanding recommendations is the consensus recommendation. The consensus recommendation is calculated for firms with a minimum of five outstanding recommendations. When measuring the optimism variable, the lower is the value the higher is the optimism. Table 2 represents the descriptive statistics that shows the recommendation optimism. As predicted, the findings reveal that on Post-Holidays, the recommendations issued have the highest optimism, while on Pre-Holidays, the recommendations issued has the least optimism. We note that on Post-Holidays, the mean and median values of optimism are the lowest; while we report the highest values on Pre-Holidays. The first illustration of day-of-the-week may be suggested in the Table 2 .

Table 2: Descriptive statistics for optimism

\begin{tabular}{lrrrrr}
\hline Statistics & $\mathrm{J}-2$ & $\mathrm{~J}-1$ & Holiday & $\mathrm{J}+1$ & $\mathrm{~J}+2$ \\
\hline Mean & 0.1445 & 0.1357 & 0.1130 & 0.1315 & 0.1031 \\
Median & 0.1300 & 0.0999 & 0.100 & 0.1333 & 0.0833 \\
Standard Deviation & 1.3336 & 1.7693 & 1.5777 & 1.1900 & 1.1133 \\
Total Recommendations & 10331 & 7333 & 6333 & 5333 & 6333 \\
\hline
\end{tabular}

This table documents the descriptive statistics for optimism during our sample period on each day. Optimism is the difference between analyst recommendation and last month's consensus recommendation. The sample period is between 2004 and 2015. The sample consists of firms listed in Morocco, Saudi Arabia, Jordan, Kuwait, United Arab Emirates, Qatar, Lebanon, Algeria, Yemen, and Bahrain.

\subsection{Control variables}

The control variables used in this paper are presented as following:

- SIZE: We use the log of market capitalization on the day of recommendation to illustrate SIZE. A study done by Lai and Teo (2008) shows that size has a moderate effect on recommendation optimism. Data for SIZE is gathered from the Datastream. 
- LEVERAGE: is the total debt to total asset ratio. Firms are exposed to distress risk due to the high degree of leverage; therefore, it may have an effect on recommendation optimism. The data for LEVERAGE is gathered from the Worldscope.

- $\quad$ EPS: are the earnings per share. Higher earnings attract stock market participants. We argue that higher earnings may lead to higher optimism in recommendations. Data for EPS is obtained from the Worldscope.

- GROWTH: We define GROWTH as growth in firm's assets. We argue that firms with high growth attract investors. Greater visibility among investors may induce analysts to issue optimistic recommendations. Data for GROWTH is obtained from the Worldscope.

- ANALYST: We define ANALYST as the total number of analysts issuing recommendations for a firm during the year. Lai and Teo (2008) show that the extent of analyst coverage has a moderating effect on recommendation optimism. Data for ANALYST is obtained from the I/B/E/S.

- EXPERIENCE: This paper defines EXPERIENCE as the number of years since analyst first appeared in the I/B/E/S database. We argue that higher experience may make analysts more independent, thereby reducing recommendation optimism. Data for EXPERIENCE is obtained from the I/B/E/S.

- STD: We define STD as the dispersion in analyst recommendations. Higher dispersion is associated with higher information uncertainty. Ackert and Athanassakos (1997) argue that analysts tend to be more biased whenever information uncertainty is high. Data for STD is obtained from the I/B/E/S.

\subsection{Methodology}

\section{$4.1 \quad$ Univariate analysis}

This section will investigate the effect of the day-of-the-week on analyst recommendations; whether the relationship exists or not. To be more specific, we intend to exhibit whether analysts issue more or less optimistic recommendations on some specific days. Table 3 shows whether there is a difference in average recommendation optimism (Panel A) and median recommendation optimism (Panel B) using different days of the week. Our findings reveal that on PRE-HOLIDAY, average and median recommendation optimism are significantly less than recommendation optimism on other days. As an instance, we show that the difference between average (median) recommendation optimism on Post-holidays and average (median) recommendation optimism on Pre-holidays is 0.0440 (0.0550). We also report from table 3, panel A, that on Post-Holidays, average recommendation optimism is significantly more than average recommendation optimism on other days. As an instance, we show that the difference between average recommendation optimism on Post-holidays and average recommendation optimism on Thursdays is 0.0236 . Our findings reveal that on other days - Tuesdays, Wednesdays, and Thursdays, there is no significant difference on average recommendation optimism.

Table 3: Difference between optimism

Panel A: Difference between average optimism

\begin{tabular}{|c|c|c|c|c|c|}
\hline Days & $\mathrm{J}-2$ & $\mathrm{~J}-1$ & Holiday & $\mathrm{J}+1$ & $\mathrm{~J}+2$ \\
\hline $\mathrm{J}-2$ & - & & & & \\
\hline $\mathrm{J}-1$ & $-0.024^{* * *}$ & - & & & \\
\hline Holiday & -0.0122 & 0.0804 & - & & \\
\hline $\mathrm{J}+1$ & $-0.044^{* * *}$ & -0.0022 & -0.0008 & - & \\
\hline $\mathrm{J}+2$ & $-0.088^{* * *}$ & $-0.0208^{* *}$ & $-0.0022^{* * *}$ & $-0.0442^{* *}$ & - \\
\hline \multicolumn{6}{|c|}{ Panel B: Difference between median optimism } \\
\hline Days & $\mathrm{J}-2$ & $\mathrm{~J}-1$ & Holiday & $\mathrm{J}+1$ & $\mathrm{~J}+2$ \\
\hline $\mathrm{J}-2$ & - & & & & \\
\hline $\mathrm{J}-1$ & $-0.044^{* * *}$ & - & & & \\
\hline Holiday & $-0.040^{*}$ & $-0.0288^{* *}$ & - & & \\
\hline $\mathrm{J}+1$ & -0.0888 & -0.240 & -0.244 & - & \\
\hline $\mathrm{J}+2$ & $-0.088^{* * *}$ & $-0.020 * * *$ & $-0.048^{* * *}$ & $-0.088^{* *}$ & - \\
\hline
\end{tabular}

This table documents the difference between optimism on different days. Optimism is the difference between analyst recommendation and last month's consensus recommendation. Panel A document differences in average optimism and Panel B documents differences in median optimism. The sample period is between 2004 and 2015. The sample consists of firms listed in Morocco, Saudi Arabia, Jordan, Kuwait, United Arab Emirates, Qatar, Lebanon, Algeria, Yemen, and Bahrain. 1\% significance is represented by ***, 5\% significance by **, and 10\% significance by *.

\subsection{Multivariate analysis}

Our hypothesis indicates that day-of-the-effect exists in analyst recommendations. For us to test the theory, we assess a regression with (OPT) as the dependent variable being the optimism of analysts and four other dummy variables which will represent the different days of the week. 
- If the recommendation is issued on Post-Holidays, POST-HOLIDAYS receives the value of 1. Otherwise, it is attributed the value of 0 .

- If the recommendation is issued on Tuesday, TUESDAY receives the value of 1 . Otherwise, it is attributed the value of 0 .

- If the recommendation is issued on Thursday, THURSDAY receives the value of 1 . Otherwise, it is attributed the value of 0 .

If the recommendation is issued on Pre-Holidays, PRE-HOLIDAYS receives the value of 1. Otherwise it is attributed the value of 0 . As mentioned above, SIZE, LEVERAGE, GROWTH, EPS, ANALYST, and EXPERIENCE are also included in the regression as control variables. To complete out regression equations, we also insert year dummies (YDUM), industry dummies (IDUM), and country dummies (CDUM). Our regression equations are presented as follow:

$$
\begin{aligned}
& O P T=\alpha+\beta_{1}(M O N D A Y)+\beta_{2}(T U E S D A Y)+\beta_{3}(T H U R S D A Y)+\beta_{4}(\text { FRIDAY })+ \\
& \sum_{\text {Year }} \beta^{\text {Year }}(\text { YDUM })+\sum_{\text {Ind }} \beta^{\text {Ind }}(I D U M)+\sum_{\text {Ctry }} \beta^{\text {Ctry }}(C D U M)+\varepsilon \\
& O P T=\alpha+\beta_{1}(M O N D A Y)+\beta_{2}(T U E S D A Y)+\beta_{3}(T H U R S D A Y)+\beta_{4}(F R I D A Y)+\beta_{5}(S I Z E) \\
& +\sum_{\text {Year }} \beta^{\text {Year }}(\text { YDUM })+\sum_{\text {Ind }} \beta^{\text {Ind }}(I D U M)+\sum_{\text {Ctry }} \beta^{\text {Ctry }}(C D U M)+\varepsilon
\end{aligned}
$$

And

$$
\begin{aligned}
& \text { OPT }=\alpha+\beta_{1}(\text { MONDAY })+\beta_{2}(\text { TUESDAY })+\beta_{3}(\text { THURSDAY })+\beta_{4}(\text { FRIDAY })+\beta_{5}(\text { SIZE }) \\
& +\beta_{6}(\text { LEVERAGE })+\beta_{7}(\text { EPS })+\beta_{8}(G R O W T H)+\beta_{9}(\text { ANALYST })+\beta_{10}(\text { EXPERIENCE }) \\
& +\sum_{\text {Year }} \beta^{\text {Year }}(\text { YDUM })+\sum_{\text {Ind }} \beta^{\text {Ind }}(I D U M)+\sum_{\text {Ctry }} \beta^{\text {Ctry }}(C D U M)+\varepsilon
\end{aligned}
$$

\begin{tabular}{|c|c|c|c|}
\hline & \multicolumn{2}{|c|}{ Table 4: Day-of-the-week effect and optimism in analyst recommendations } & \\
\hline & Equation (1) & Equation (2) & Equation (3) \\
\hline $\mathrm{J}-2$ & $-0.0222^{* *}$ & $-0.0444^{* *}$ & $-0.0844^{* *}$ \\
\hline $\mathrm{J}-1$ & -0.0024 & -0.0044 & -0.0088 \\
\hline $\mathrm{J}+1$ & 0.0222 & 0.0024 & -0.0002 \\
\hline $\mathrm{J}+2$ & $0.0444^{* * *}$ & $0.0222^{* * *}$ & $0.0288^{* *}$ \\
\hline Size & & $0.0044^{* * *}$ & $0.00244^{*}$ \\
\hline Leverage & & & $-0.0044^{* *}$ \\
\hline Eps & & & -0.0004 \\
\hline Growth & & & $-0.0088^{* * *}$ \\
\hline Analyst & & & 0.0008 \\
\hline Experience & & & $-0.0088^{* * *}$ \\
\hline Std & & & $-0.4888^{* * *}$ \\
\hline Industry Dummies & Yes & Yes & Yes \\
\hline Year Dummies & Yes & Yes & Yes \\
\hline Country Dummies & Yes & Yes & Yes \\
\hline No. of Observations & 2440 & 8888 & 4443 \\
\hline F-value & 18.44 & 24.22 & 34.00 \\
\hline Adjusted R-square & 0.04 & 0.04 & 0.022 \\
\hline $\begin{array}{l}\text { This table uses Equ } \\
\text { recommendation opti } \\
\text { 2015. The sample cons } \\
\text { Lebanon, Algeria, Yem } \\
\text { significance by*. }\end{array}$ & $\begin{array}{l}\text { (2), and Equ } \\
\text { oefore and after } \\
\text { Morocco, Saud } \\
\text { significance is }\end{array}$ & $\begin{array}{l}\text { document the } \\
\text { he sample peri } \\
\text { n, Kuwait, Unit } \\
\text { by } * * *, 5 \% \text { sign }\end{array}$ & $\begin{array}{l}\text { ship between } \\
\text { veen } 2004 \text { and } \\
\text { mirates, Qatar, } \\
y^{* *} \text {, and } 10 \%\end{array}$ \\
\hline
\end{tabular}

Table 4 shows the results of our analysis. Our findings show the presence of a day-of-the-week effect in analyst recommendations; we assert that the most optimistic recommendations are issued on Post-Holidays period. For all equations, the coefficient of POST-HOLIDAYS is significantly negative. We suggest that the day-of-the-week effect in returns is the source of the day-of-the-week effect in analyst recommendations. 
For the analysts to amend between optimistic biases in their recommendations and their reputation as an unbiased investment advisor, Post-Holidays period is for analysts the most favorable period to issue the most optimistic recommendations. Analysts will be relieving pressure from employers to issue optimistic recommendations, at the same time assure that return would trend upwards in the short-term.

Our findings also indicate that recommendations issued on Pre-holidays are the most pessimistic. For all equations, the coefficient of PRE-HOLIDAYS is significantly negative. We suggest that by issuing bulk of unfavorable recommendations on Pre-Holidays, analysts expect the short-term returns would trend downwards.

\subsection{Robustness checks}

\subsubsection{Day-of-the-week effect and optimism in analyst recommendations (alternate measure)}

To check the robustness, we re-estimate Equation (1), Equation (2), and Equation (3) using an alternate measure of optimism being the difference between analyst's current recommendation and the median of last month's outstanding recommendations. The results are shown in Table 5 which are qualitatively similar to those shown in Table 4. We report higher optimism in recommendations issued on Post-holidays and lower optimism in recommendations issued on Pre-holidays. All equations reveal a negative coefficient of POST-HOLIDAYS and a positive coefficient of PRE-HOLIDAYS.

Table 5: Day-of-the-week effect and optimism in analyst recommendations (alternate measure)

\begin{tabular}{|c|c|c|c|}
\hline & Equation (1) & Equation (2) & Equation (3) \\
\hline $\mathrm{J}-2$ & $-0.0022^{* *}$ & $-0.0044^{* *}$ & $-0.0022^{* * *}$ \\
\hline $\mathrm{J}-0$ & -0.0088 & -0.0044 & -0.0086 \\
\hline $\mathrm{J}+1$ & 0.0044 & 0.0024 & -0.0008 \\
\hline $\mathrm{J}+2$ & $0.0220^{* * *}$ & $0.0028 * * *$ & $0.0066^{*}$ \\
\hline Size & & 0.0022 & $0.0022^{* * *}$ \\
\hline Leverage & & & $-0.0000^{* *}$ \\
\hline Eps & & & 0.0004 \\
\hline Growth & & & $-0.0000^{* * *}$ \\
\hline Analyst & & & $-0.0048^{* * *}$ \\
\hline Experience & & & $-0.0044^{* * *}$ \\
\hline Std & & & $-0.0668^{* * *}$ \\
\hline Industry Dummies & Yes & Yes & Yes \\
\hline Year Dummies & Yes & Yes & Yes \\
\hline Country Dummies & Yes & Yes & Yes \\
\hline No. of Observations & 2144 & 6022 & 4200 \\
\hline F-value & 20.22 & 06.64 & 22.22 \\
\hline Adjusted R-square & 0.04 & 0.01 & 0.04 \\
\hline \multicolumn{4}{|c|}{$\begin{array}{l}\text { This table uses Equation (1), Equation (2), and Equation (3) to document the relationship between recommendation } \\
\text { optimism (using an alternate measure) and two days before and after the holiday. The sample period is between } \\
2004 \text { and } 2015 \text {. The sample consists of firms listed in Morocco, Saudi Arabia, Jordan, Kuwait, United Arab Emirates, } \\
\text { Qatar, Lebanon, Algeria, Yemen, and Bahrain. } 1 \% \text { significance is represented by }{ }^{* *}, 5 \% \text { significance by }{ }^{* *} \text {, and } 10 \% \\
\text { significance by*. }\end{array}$} \\
\hline
\end{tabular}

\subsubsection{Day-of-the-week effect and optimism in analyst recommendations (quantile regression approach)}

Our analysis entails that any analyzed point on the conditional distribution results in the same estimates of the relationship between optimism in an analyst recommendation and day-of-the-week effect. While testing particularly for linearity and the LINE assumptions, we conclude that the linearity assumption holds. We applied a quantile regression to test the empirical effectiveness of the assumption and to examine day-of-the-week at different points of conditional distribution of optimism in analyst recommendations; the quantile regression is implemented at five quantiles $(0.10,0.30,0.50,0.70$, and 0.90$)$.

Table 6 reports the results of our analysis, proving that the relationship between recommendations issued on Post-Holidays and optimism is accurate only in lower quantiles. POST-HOLIDAYS for the $10^{\text {th }}, 30^{\text {th }}$, and $50^{\text {th }}$ quantile report a negative coefficient. As for the two quantiles left, namely the $70^{\text {th }}$ and $90^{\text {th }}$. We reveal insignificant coefficient of POST-HOLIDAYS. By comparing Table 4 and with our results, we report that at the $10^{\text {th }}$ and $30^{\text {th }}$ quantile, the relationship is underestimated. We also proved that the relationship between recommendations issued on Pre-Holidays and optimism is only valid in higher quantiles. PRE-HOLIDAYS for the $50^{\text {th }}, 70^{\text {th }}$, and $90^{\text {th }}$ quantile report a positive coefficient. As for the two quantiles left, namely the $10^{\text {th }}$ and $30^{\text {th }}$. We reveal insignificant coefficient of PRE-HOLIDAYS. By comparing Table 4 and with our results, we report that at the $50^{\text {th }}, 70^{\text {th }}$ and $90^{\text {th }}$ quantile, OLS regression underestimates the relationship. 


\begin{tabular}{lrrrrr}
\hline \multicolumn{5}{c}{ Table 6: Day-of-the-week effect and optimism in analyst recommendations } & (quantile regression approach) \\
& 0.10 & 0.30 & 0.50 & 0.70 & 0.90 \\
\hline J-2 & $-0.0684^{* * *}$ & $-0.0242^{* * *}$ & $-0.0222^{*}$ & -0.0022 & -0.0044 \\
J-1 & -0.0222 & -0.0022 & 0.0022 & 0.0022 & -0.0028 \\
J+1 & $-0.0024^{* * *}$ & -0.0022 & -0.0066 & 0.0222 & 0.0066 \\
J+2 & -0.0266 & 0.0066 & $0.0224^{* *}$ & $0.0222^{* *}$ & $0.0468^{* * *}$ \\
Size & $0.0448^{* * *}$ & $0.0486^{* * *}$ & $-0.0004^{*}$ & $-0.0086^{* *}$ & $-0.0868^{* * *}$ \\
Leverage & -0.0088 & $-0.0044^{* * *}$ & -0.0008 & $-0.0002^{* *}$ & 0.0022 \\
Eps & 0.0008 & -0.0008 & $-0.0088^{*}$ & $-0.0028^{* * *}$ & -0.0048 \\
Growth & $-0.0088^{* * *}$ & $-0.0020^{* * *}$ & $-0.0002^{* * *}$ & $-0.00888^{* * *}$ & $-0.0048^{* * *}$ \\
Analyst & $-0.0044^{* *}$ & -0.0022 & $0.0002^{* *}$ & -0.00668 & $0.0066^{* * *}$ \\
Experience & $-0.0024^{* *}$ & $-0.0088^{* *}$ & $-0.0044^{* * *}$ & $-0.00444^{* * *}$ & $-0.0088^{* * *}$ \\
Std & $-0.4222^{* * *}$ & $-0.4468^{* *}$ & $-0.2220^{* * *}$ & $-0.6886^{* * *}$ & $-0.2224^{* * *}$ \\
Industry Dummies & Yes & Yes & Yes & Yes & Yes \\
Year Dummies & Yes & Yes & Yes & Yes & Yes \\
Country Dummies & Yes & Yes & Yes & Yes & Yes \\
No. & 2882 & 4862 & 4822 & 1882 & 2862 \\
Observations & & & & & \\
F-value & & & & & \\
Adjusted R-square & 0.022 & 0.028 & 0.008 & 0.022 & 0.008 \\
\hline
\end{tabular}

This table uses quantile regression and Equation (3) to document the relationship between recommendation optimism and two days before and after the holiday. The sample period is between 2004 and 2015. The sample consists of firms listed in Morocco, Saudi Arabia, Jordan, Kuwait, United Arab Emirates, Qatar, Lebanon, Algeria, Yemen, and Bahrain. 1\% significance is represented by ***, $5 \%$ significance by **, and $10 \%$ significance by *

\subsubsection{Day-of-the-week effect and optimism in analyst recommendations (level of recommendations)}

As a last robustness check, we substitute optimism measure with the level of recommendations. Given that level of recommendation is an ordinal variable, we use ordered probit regressions to estimate Equation (1), Equation (2), and Equation (3). ${ }^{2}$ Table 7 reports the results of our analysis, showing that on Pre-holidays, analysts are more likely to issue pessimistic recommendations (Underperform and Sell). For all equations, we state a significantly positive coefficient of PRE-HOLIDAYS. Our findings from Equation (6) being the most comprehensive equation, shows that on Post-holidays, analysts are more likely to issue optimistic recommendations (Strong Buy and Buy)

Table 7: Day-of-the-week effect and optimism in analyst recommendations (level of recommendations)

\begin{tabular}{|c|c|c|c|}
\hline & Equation (4) & Equation (5) & Equation (6) \\
\hline $\mathrm{J}-2$ & -0.0044 & -0.0088 & $-0.0224^{* *}$ \\
\hline $\mathrm{J}-1$ & 0.0006 & 0.0086 & -0.0026 \\
\hline $\mathrm{J}+1$ & -0.0006 & -0.0022 & -0.0088 \\
\hline $\mathrm{J}+2$ & $0.0660^{* * *}$ & $0.0224 * * *$ & $0.0888^{* * *}$ \\
\hline Size & & $-0.0444^{* * *}$ & $-0.0444^{* * *}$ \\
\hline Leverage & & & $0.0008^{* * *}$ \\
\hline Eps & & & $-0.0044^{* * *}$ \\
\hline Growth & & & $-0.0044^{* * *}$ \\
\hline Analyst & & & $0.0088^{* * *}$ \\
\hline Experience & & & $-0.0066^{* * *}$ \\
\hline Std & & & $0.2242^{* * *}$ \\
\hline Industry Dummies & Yes & Yes & Yes \\
\hline Year Dummies & Yes & Yes & Yes \\
\hline Country Dummies & Yes & Yes & Yes \\
\hline No. of Observations & 6620 & 1888 & 6822 \\
\hline Wald Chi2 & 244.22 & 222.46 & 420.22 \\
\hline Pseudo R-square & 0.02 & 0.02 & 0.08 \\
\hline \multicolumn{4}{|c|}{$\begin{array}{l}\text { This table uses Equation (1), Equation (2), and Equation (3) to document the relationship between the level of } \\
\text { recommendations and two days before and after the holiday. The sample period is between } 2004 \text { and } 2015 . \\
\text { The sample consists of firms listed in Morocco, Saudi Arabia, Jordan, Kuwait, United Arab Emirates, Qatar, } \\
\text { Lebanon, Algeria, Yemen, and Bahrain. 1\% significance is represented by **, 5\% significance by **, and } 10 \% \\
\text { significance by*. }\end{array}$} \\
\hline
\end{tabular}

\footnotetext{
${ }^{2}$ Level of recommendation is coded as follows: 1 for Strong Buy, 2 for Buy, 3 for Hold, 4 for Underperform, and 5 for Sell.
} 


\subsection{Discussion of results}

\subsubsection{Information uncertainty and day-of-the-week effect}

Prior literature shows that stocks with higher uncertainty are more exposed to behavioral biases Ackert and Athanassakos (1997). They argue that the higher is the information uncertainty, the higher is the tendency for analysts to be biased. Once there is information uncertainty, reputation tends to be less of concern for analysts. As a result, certain information environment could be less exposed to day-of-the-week effect. To react to these possibilities. To react to these concerns, we break our sample into -first sub-sample formed by firms with above average dispersion in analyst recommendations and the second sub-sample is formed of firms with below average dispersion in analyst recommendations.

Equation (3) is re-estimated for both sub-samples. Table 8 reports the results of our analysis, showing that in firms with higher information uncertainty, the day-of-the-week effect is absent. For sub-sample with below average dispersion in analyst recommendations, we showed insignificant coefficients of both PRE-HOLIDAYS and POST-HOLIDAYS. Table 8 reveals that firms with higher information uncertainty are the ones exposed to day-ofthe-week effect. For this sub-sample, we showed significant coefficients of both PRE-HOLIDAYS and POSTHOLIDAYS. Our argument that once information uncertainty is high, behavioral biases are more present, holds is consistent with Ackert and Athanassakos (1997).

\begin{tabular}{lrr}
\hline & Table 8: Information uncertainty and day-of-the-week effect \\
\hline & Low Information Uncertainty & High Information Uncertainty \\
\hline $\mathrm{J}-2$ & $-0.0000^{* *}$ & $-0.0224^{* *}$ \\
$\mathrm{~J}-1$ & $-0.0224^{*}$ & $0.0466^{* *}$ \\
$\mathrm{~J}+1$ & $-0.0088^{* *}$ & $0.0022^{*}$ \\
$\mathrm{~J}+2$ & $0.0044^{*}$ & $0.0866^{* * *}$ \\
Size & $0.0082^{* *}$ & $0.0088^{*}$ \\
Leverage & $-0.0004^{* *}$ & $-0.0022^{* *}$ \\
Eps & -0.0026 & $-0.0004^{*}$ \\
Growth & $-0.0066^{* * *}$ & $-0.0022^{* * *}$ \\
Analyst & 0.0044 & $0.0008^{*}$ \\
Experience & $-0.0088^{* * *}$ & $-0.0066^{* * *}$ \\
Std & $-0.4644^{* * *}$ & $-0.4466^{* * *}$ \\
Industry Dummies & Yes & Yes \\
Year Dummies & Yes & Yes \\
Country Dummies & Yes & Yes \\
No. of Observations & 4464 & 2286 \\
F-value & 8.40 & 8.68 \\
Adjusted R-square & 0.066 & 0.080 \\
\hline This table uses Equation (3) to document the effect of information uncertainty on holidays' effect. The sample \\
period is between 2004 and 2015. The sample consists of firms listed in Morocco, Saudi Arabia, Jordan, Kuwait, \\
United Arab Emirates, Qatar, Lebanon, Algeria, Yemen, and Bahrain. 1\% significance is represented by ***, 5\% \\
significance by **, and 10\% significance by *.
\end{tabular}

\subsubsection{Analyst experience and day-of-the-week effect}

Our findings are restricted to analysts with less experience, which waken our concerns about the matter. Analysts with less experience may be more susceptible to pressures from their employers. Analysts with more experience, considering their skills and larger networks; in contrast, may be less susceptible to pressures from their employers. To react to these concerns, we break our sample into -first sub-sample formed by analysts with above average experience and the second sub-sample is formed of firms with below average experience. Equation (3) is re-estimated for both sub-samples. Table 9 shows the results of our analysis, showing that analysts with low experience tend to be more optimistic.

For the recommendations issued by less experienced analysts, we state a significantly negative coefficient of POST-HOLIDAYS. Our argument is stating that because of the pressures faced by employers, less experienced analysts are more likely to issue optimistic recommendations. We also argue that on PRE-HOLIDAYS, analysts with more experience tend to issue less optimistic recommendations. For the recommendations issue by more experienced analysts on PRE-HOLIDAYS, we report a significantly positive coefficient. We, therefore, argue that due to the skills and larger networks that analysts with high experience own, they can oppose the pressures from employers to issue optimistic recommendations. 


\begin{tabular}{lrr}
\hline & Table 9: Analyst experience and day-of-the-week effect & High Analyst Experience \\
\hline J-2 & Low Analyst Experience & 0.0024 \\
$\mathrm{~J}-1$ & $-0.0447^{* * *}$ & 0.0224 \\
$\mathrm{~J}+1$ & $-0.0444^{* *}$ & 0.0944 \\
$\mathrm{~J}+2$ & $-0.0667^{* *}$ & $0.0666^{* * *}$ \\
Size & 0.0046 & $0.0044^{*}$ \\
Leverage & 0.0066 & $-0.0046^{* * *}$ \\
Eps & -0.0066 & -0.0066 \\
Growth & $-0.0006^{*}$ & $-0.0044^{* * *}$ \\
Analyst & $-0.0066^{* * *}$ & 0.0044 \\
Experience & 0.0022 & $-0.0046^{* * *}$ \\
Std & $0.0006^{* * *}$ & $-0.4664^{* * *}$ \\
Industry Dummies & $-0.6666^{* * *}$ & Yes \\
Year Dummies & Yes & Yes \\
Country Dummies & Yes & Yes \\
No. of Observations & Yes & 4667 \\
F-value & 1444 & 34.26 \\
Adjusted R-square & 14.44 & 0.024 \\
\hline This table uses Equation (3) to document the effect of analyst experience on holidays' effect. The sample period \\
is between 2004 and 2015. The sample consists of firms listed in Morocco, Saudi Arabia, Jordan, Kuwait, United \\
Arab Emirates, Qatar, Lebanon, Algeria, Yemen, and Bahrain. $1 \%$ significance is represented by ${ }^{* * *}, 5 \%$ \\
significance by ${ }^{* *}$, and 10\% significance by $*$
\end{tabular}

\subsection{Conclusions}

This paper investigates the presence of religious holidays effect in analyst recommendations in MENA countries' stock markets (Morocco, United Arab Emirates, Saudi Arabia, Jordan, Kuwait, Lebanon, Qatar, Algeria, Bahrain) during the period between 2004 and 2015. Our findings reveal that on Pre-Holidays, analysts tend to issue pessimistic recommendations, and issue optimistic recommendations on Post-Holidays. Our results are robust to alternate measures of optimism and after controlling for various firm-specific characteristics. Prior literature on day-of -the week effect is consonant with our results which document an increase in stock prices during the week, and a slight decrease in stock prices over the weekend. We argue that analysts can benefit from the upward trend in stock prices during Post-Holidays by issuing an optimistic recommendation. Analysts may as well benefit from the downward trend in stock prices by issuing pessimistic recommendations on Pre-Holidays. Last but not least we also showed that our findings are more evident among analyst with less experience and in firms with higher information uncertainty. For eventual research, we suggest constructing buy-and-hold portfolios that are designed by relying on recommendations issued on each day of the week and computing their performance.

\section{References}

Ajinkya, B. B., R. K. Atiase, and M. J. Gift, 1991, Volume of Trading and the Dispersion in Financial Analysts' Earnings Forecasts, Accounting Review 66, 389-401.

Al-Hajieh, H. Redhead, K. \& Rodgers, T. (2011). Investor sentiment and calendar anomaly effects: A case study of the impact of Ramadan on Islamic Middle Eastern markets. Research in International Business and Finance, 25, 345- 356. http://dx.doi.org/10.1016/j.ribaf.2011.03.004

Barber, B., R. Lehavy, M. McNichols, and B. Trueman, 2001, Can Investors Profit from the Prophets? Security Analyst Recommendations and Stock Returns, Journal of Finance 56, 531-563. http://dx.doi.org/10.1111/0022-1082.00336

Barber, B., R. Lehavy, and B. Trueman, 2007, Comparing the Stock Recommendation Performance of Investment Banks and Independent Research Firms, Journal of Financial Economics 85, 490517. http://dx.doi.org/10.1016/j.jfineco.2005.09.004

Barro, R. J., \& McCleary, R. (2003). Religion and economic growth (No. w9682). National Bureau of Economic Research. http://dx.doi.org/10.3386/w9682

Bialkowski, J., Etebari, A., \& Wisniewski, T.P., (2010) Piety and Profits: stock market anomaly during the Muslim Holy month. Working paper No. 52/2010, University of Canterbury Christchurch, New Zealand.

Brown, Phillip, George Foster, and Eric Noreen, 1985, Security Analyst Multi-Year Earnings Forecasts and the Capital Market, American Accounting Association: Sarasota, FL. 
Chan, L. K. C., J. Karceski, and J. Lakonishok, 2007, Analysts' Conflicts of Interest and Biases in Earnings Forecasts, Journal of Financial and Quantitative Analysis 42, 893-914 http://dx.doi.org/10.1017/S0022109000003434

Chowdhury, T. S. \&Mostari, S. (2015). Impact of Eid-ul-Azha on Market Return in Dhaka Stock Exchange. Journal of Business and Management. Volume 17, Issue 2. PP 25-29.

Clement, M. B., and S. Y. Tse, 2005, Financial Analyst Characteristics and Herding Behavior in Forecasting, Journal of Finance 60, 307-341. http://dx.doi.org/10.1111/j.1540-6261.2005.00731.x

Francis, J., Philbrick, D., 1993. Analysts' decisions as product of multi-task environment. Journal of Accounting Research. 31, 216-230. http://dx.doi.org/10.2307/2491271

Hayes, R. M., 1998, The Impact of Trading Commission Incentives on Analysts' Stock Coverage Decisions and Earnings Forecasts, Journal of Accounting Research 36, 299-320. http://dx.doi.org/10.2307/2491479

Heflin, F., Subramanyam, K.R. and Zhang Y., 2003. Regulation FD and the financial information environment: early evidence. Accounting Review. 78, 1-37. http://dx.doi.org/10.2308/accr.2003.78.1.1

Hong, H. and Kubik, J., 2003. Analyzing the analysts: career concerns and biased earnings forecasts Journal of Finance. 58, 313-351. http://dx.doi.org/10.1111/1540-6261.00526

Hong, H., Kubik, J. D., Stein, J. C., Lins, K., Shleifer, A., \& Wurgler, J. (2002). Thy Neighbor's Portfolio: Word-of-Mouth Effects. In Ohio State University.

Hong, H., Kubik, J. D., \& Stein, J. C. (2004). Social interaction and stock-market participation. The journal of finance, 59(1), 137-163. http://dx.doi.org/10.1111/j.1540-6261.2004.00629.x

Jackson, A., 2005. Trade generation, reputation and sell-side analysis. Journal of Finance. 60, 673-717. http://dx.doi.org/10.1111/j.1540-6261.2005.00743.x

Jegadeesh, N., J. Kim, S. D. Krische, and C. M. C. Lee, 2004, Analyzing the Analysts: When do Recommendations Add Value? Journal of Finance 59, 1083-1124. http://dx.doi.org/10.1111/j.1540-6261.2004.00657.x

Jegadeesh, N., \& Kim, W. (2010). Do analysts herd? An analysis of recommendations and market reactions. Review of Financial Studies, 23(2), 901-937. http://dx.doi.org/10.1093/rfs/hhp093

Lee, M. H. \&Hamzah, N. A. (2010). Calendar variation model based on Time Series on Regression for sales forecasts: The Ramadhan effects. Proceedings of the Regional Conference Statistical Sciences (RCSS'10), 3041 ISBN 978-967-363-157-5.

Lim, T., (2001). Rationality and analysts' forecast bias. Journal of Finance. 56, 369-385. http://dx.doi.org/10.1111/0022-1082.00329

Ljungqvist, A., F. Marston, and W. J. Wilhelm Jr., 2006, Competing for Securities Underwriting Mandates: Banking Relationships and Analyst Recommendations, Journal of Finance 61, 301-340. http://dx.doi.org/10.1111/j.1540-6261.2006.00837.x

Ljungqvist, A., F. Marston, and W. J. Wilhelm Jr., 2009, Scaling the Hierarchy: How and Why Investment Banks Compete for Syndicate Co-Management Appointments, Review of Financial Studies 22, 39774007 http://dx.doi.org/10.1093/rfs/hhn106

Loh, R. K., \& Stulz, R. M. (2011). When are analyst recommendation changes influential? Review of Financial Studies, 24(2), 593-627. http://dx.doi.org/10.1093/rfs/hhq094

Malmendier, U., and D. Shanthikumar, 2007, Are Small Investors Naïve about Incentives? Journal of Financial Economics 85, 457-489. http://dx.doi.org/10.1016/j.jfineco.2007.02.001

Maremont, M., and C. Bray, 2004, In Latest Tyco Twist, Favored Analyst got Private Eye, Gratis, Wall Street Journal, 21 January, A1. Mehran, H., and R. Stulz, 2007, The Economics of Conflicts of Interest in Financial Institutions, Journal of Financial Economics 85, 267-296.

Michaely, R., and Womack K., 1999, Conflict of Interest and the Credibility of Underwriter Analyst Recommendations, Review of Financial Studies 12, 653-686. http://dx.doi.org/10.1093/rfs/12.4.653

Michaely, R., and Womack K., 1999, Conflict of interest and the credibility of underwriter analyst recommendations, Review of Financial Studies 12, 653-686. http://dx.doi.org/10.1093/rfs/12.4.653

Ramezani, A., A., H. (2013). "Studying Impact of Ramadanon Stock Exchange Index: Case of Iran", World of Sciences Journal, 1(12), 46-54.

Satt, H., (2016) "Holidays' effect and optimism in analyst recommendations: Evidence from Europe". Corporate Ownership and Control journal. Volume 13, issue 03.

Satt, H., (2016) "Do high levels of analyst following improve companies' credit ratings: Evidence from MENA region?" Forthcoming, Journal of Financial Studies \& Research.

Satt, H., (2016) "The Impact of analysts' recommendations on the Cost of Debt: International Evidence." European Journal of Contemporary Economics and Management. May 2016 Edition Vol.3 No.1. ISSN: 2411-443X.

Satt, H., (2015) "The Impact of positive cash operating activities on bonds' pricing: International Evidence." Journal of Corporate and Ownership Control, 12.4, pp. 708-717.

Usmani, M.T. (2014) Muharram: The Start of the Islamic Calendar 10/24/2014 IC0303-1877. http://www.islamicity.com/articles/Articles.asp

Yaktrakis, P., \& Williams, A. (2010). The Jewish Holiday Effect: Sell Rosh Hashanah, Buy Yom Kippur. Advances in Business Research, 1(1), 45-52. 